\title{
Studies on Zinc and Endocrine Organ
}

I. Distributions of endogenous $\mathrm{Zn}$ in severalendocrine organs of the albino rats in normal and expreimental conditions

By

\section{Keiko ONO}

Department of Physiological Chemistry, Institute of Endocrinology, Gunma University, Maebashi (Director : Prof. Hiroo Takikawa)

Polarographic measurements of endogenous $\mathrm{Zn}$ were made with soluble and insoluble fractions of several endocrine organs (pituitary gland, thyroid gland, parotid gland, submaxillary gland, thymus, pancreas, seminal vesicle and blood) of the male albino rats in normal and experimental conditions, in the latter of which animals were adrenalectomized and/or injected with DOCA or cortisone acetate.

1. Injection of DOCA or cortisone into nomal rats did not change in the contents of $\mathrm{Zn}$ in the most of the organs, with two exceptions, one of which is significant decrease in $\mathrm{Zn}$ content in both of soluble and insoluble fractions obtained from the pancreas, and the other increase in $\mathrm{Zn}$ content in the testis.

2. $\mathrm{Zn}$ contents in the most of the organs of the adrenalectomized rats showed a tendency to increase, which was recovered by injections with DOCA or cortisone. In pancreas, however, adrenalectomy together with the injections of the hormones showed significant decrease in the $\mathrm{Zn}$ contents.

3. Increase of $\mathrm{Zn}$ contents in soluble and insoluble fractions induced by adrenalectomy was restored more efficiently by DOCA than by cortisone.

\section{Studies on Zinc and Endocrine Organ}

I.I Distributions of exogenous $\mathrm{Zn}^{65}$ in several endocrine organs and tissues of the albino rats in normal and experimental condition

By

\section{Keiko ONO}

Department of Physiological Chemistry, Institute of Endocrinology, Gunma University, Maebashi (Director : Prof. Hiroo Takikawa)

Distributions of $\mathrm{Zn}^{65}$ injected intramuscularly were investigated with several organs (pituitary gland, thyroid gland, thymus, parotid gland, submaxillary gland, pancreas, testis, seminal vesicle, prostate, kidney, muscle and blood) of normal-, adrenalectomized-, adrenalectomized plus injected with DOGA or cortisone-rats, using $\gamma$-counting well type scintillation counters.

1. Most of the tissues were shown to be highest in the specific activities at seven hours or 2 days after the injection of $\mathrm{Zn}^{65}$ in normal rats. Adrenalectomy was responded by delayed $\mathrm{Zn}^{65}$ uptake to and/or excretion from the tissues investigated. Effect of adrenalectomy on the uptake and excretion of exogenous $\mathrm{Zn}^{65}$ was restored by injection with DOGA or cortisone, the former of which was more effective to the ability of the restoration than the latter. 
2. Distribution of exogenous $\mathrm{Zn}^{65}$ in soluble fractions of the homogenized tissues was measured with the following results: Percentages of $\mathrm{Zn}^{65}$ in soluble and insoluble fractions of each organ to sum of the activities of the the both fractions were not appreciably changed by adrenalectomy or injections of the hormones used in the present study. Larger amount of the activity in the soluble fraction than in the insoluble fraction was found in pituitary gland, thyroid gland, pancreas, spleen, liver and kidney, especially in the pancreas, and vice versa in seminal vesicle, prostate and muscle. In other organs, parotid gland, submaxillary gland and thymus, the activity was nearly equally divided into soluble and insoluble fractions.

3. Functional interrelationships between $\mathrm{Zn}^{65}$ and endocrine organs were discussed in relation to the physiological significance of endogenous $\mathrm{Zn}$.

\section{The Influence of Several Endocrine Factors upon the Growth of Pigment-Epithelium of the Retina Cultivated in vitro, with Special Reference to the Influence upon the Distribution of Pigment Granules in the Cell Protoplasm}

By

\section{Hirofumi SAKAGAMI}

1st Department of Internal Medicine, the Kyoto Prefectural University of Medicine

(Director : Prof. H. Yoshida M.D.)

Pigment epithelium of the retina, embryologically, belongs to the nervous system, and its role in the visual function is exstremely important.

Using the retina of chick embryo, tissue culture experiments were performed by single cover slip method or by roller test tubes, and the growing process of pigment epithelium is measured by planometric means. Observations of cytological components of the growing cells were made by histochemical technics or with the aid of phase contrast microscope.

On the course of the experiments, several types of hormones were supplied to the nutritional media so that the influence of each hormone on the growth of the epithelium, especially of the pigment granules therein, might be examined.

The findings of the present experiments are as follows.

Chapter I

(1) Submitted to the tests are the pigment-epithelia of the retina extracted from chick embryo of between 8 and 11 days' incubation, that has proved to produce good results through preliminaly experiments.

The epithelia cultured by single cover slip method grow, by 96 hours, about 8.5 to 9.7 times in space.

By roller test tubes, there is one case the epithelium grow 8.74 times, until it stopped to grow after 168 hours.

(2) The pigment epithelia of the retina grow rapidly after the incubation period of 24 hours, forming a typical epithelial sheeth.

Vol. 36 No. 8 


\title{
亜鉛と内分泌腺の関 係 (第2 報) \\ ラッテの内分泌蔵器中の $\operatorname{Zn} 65$ の分布について
}

\author{
群馬大学 内分泌研究所 藏器化学部 (主任 滝川決男教授) \\ 小野恵子
}

（本論文の要旨は筑 7 回日本内分泌学会東部部会総会で発表した）

\begin{abstract}
緒 言

亜鉛が内分泌腺や血渡あるいはその他の臟器に存在し，その活動に何らかの機能的な関係を有しているこ

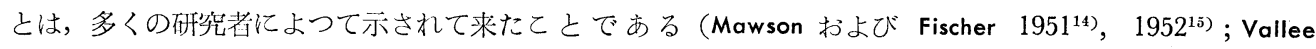
1956 ${ }^{23)}$ ，195724) ; Drinker および Collier 19263). しかしながらその生理的意義についてはインシュリン等の 蛋白性ホルモンに対する作用之，いわりる金属酵素として知られている炭酸脱水素酶素など数種の醥素の構 成要素として重要性が認められている他には，各臟器中に見出されるZn が如何なる生理機能に結びついて いるかは全く解つていない。

近年に至り，放射性 $\mathrm{Zn}^{65}$ を用いることによつて，各種臟器における亜鉛の代謝の研究が盛んになつて来 た (Montgomery et al. 1943 ${ }^{18}$; Sheline et al. 1943) ${ }^{19220)}$. 特に注目されているのは, 前立腺における $\mathrm{Zn}^{65}$ の代謝であつて，乙の組織䍗取される $\mathrm{Zn}^{6 \check{5}}$ はその動物の生理的又は病理的条件によりいちじるしく变動

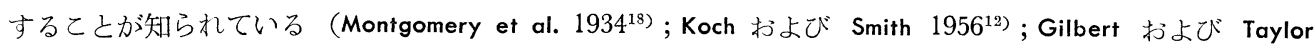
1956 ; Wolff 1956 ${ }^{25)}$; Gunn および Gould 1956, 1957 ; Sheline et al. 194320)).

Gunn および Gould $\left.\left(1956^{7}\right), 1957^{8}\right)$ )よよればラッテの前立腺への $\mathrm{Zn}^{65}$ の摂取率は脳下垂体剔出や去梦に より低下するが，てれに適当量の Androgen または Estrogen を注射すると，正常值に保つととができる. また正常の雄ラッテに適当量の性ホルモンを投与すると逆に前立腺への $\mathrm{Zn}^{65}$ の摂取を妨げる. 同じことは

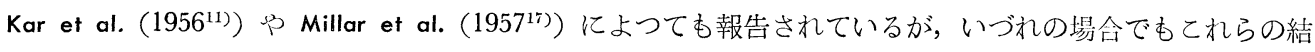
果のもつ生理的意義はわからないとのべている，筆者は前の報告に (小野195926) 副剔ラッテ及びそれらに DOCA，又は Cortisone を投与した際の各内分泌臓器中の $\mathrm{Zn}$ の含量を求めたが，更に $\mathrm{Zn}^{65}$ を投与した際 の各蔵器における $\mathrm{Zn}^{65}$ の摂取率を求めその分布を調べたので報告する.
\end{abstract}

\section{実験材料並びに実験方法}

実験動物には，本学純系動物舎で飼育した体重 $150 \mathrm{~g}$ 前後の Wister 系成熟雄ラッテ，80匹を用いた。この あのを 4 群に分け第 1 群を無処置対照とし, 第 2 群は副腎剔出のみ, 第 3 群は副腎剔出後 DOCA 投与, 第 4 群は副腎剔出後 Cortisone を投与した。 乙れらのラッテは，すべて代謝籠に入れ一定条件下 $\left(25 \pm 2{ }^{\circ} \mathrm{C}\right)$ で飼育した。飼料はオリエンタル固型飼料（小麦粉 $33.0 \%$ ，粟粉 $23.0 \% ，$ とう万こし粉 $10.0 \%$ ，米棣 5.0 $\%$, 数 $10.0 \%$, 魚粉 $14.0 \%$, ビタミン $\mathrm{AD}$ (チョコラA) $0.1 \%$, 綿㬰油 $0.4 \%$, 食塩 $0.5 \%$, 炭酸カルシュ ウム（コロイカル） $0.5 \%$ 及びイースト $3.5 \%$ であり，K含有量は $8.8 \mathrm{mg} / \mathrm{g}$ であり $\mathrm{Na}$ 含有量は $3.2 \mathrm{mg} / \mathrm{g}$ ) 用 いた.

$\mathrm{Zn}^{65}$ は Carrier Free の $\mathrm{Zn}^{65} \mathrm{Cl}_{2}$ を用い，生理的食塩水で20ml中5mcになる様に稀釈し体重100gにつき $40 \mu \mathrm{c}$ 宛, 副剔手術後直ちに実験群及び対照群の右足大煺部に筋肉内注射を行い，直ちに第 3 群および第 4 群 には夫々 DOGA, Cortisone 在投与した。

DOGA 投与侰作は DOCA (帝国藏器) の2.5mgt, Cortisone 投与群には Cortisone acetate(MERCK) の0.25 mgをそれぞれ $1 \mathrm{ml}$ のアルコール添加の水溶液で溶解したものを, 副剔群には対照としてアルコール 
添加の雚溜水のみを 1 日 1 回 $0.1 \mathrm{ml}$ づつ背部皮下注射を行つた。乙れ等の最初の注射の 7 時間後及び 2 日, 5 日，10日目の注射からそれぞれ 24 時間後に断頭致死せしめ血液の $2 \mathrm{ml}$ を゚リチレン製試験管にとり，直ち

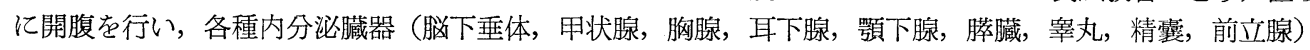
及び刘照として, 肝藏, 脾藏, 筋肉 (左足大腿部) をそれぞれ適当量採取し, 科量の後, Well type シンチ レーションカウンターで組織中の放射能を測定した，その後それ等藏器を臟器重量 $100 \mathrm{mg}$ 亿つき， $1 \mathrm{ml}$ の水 を加え冷却し乍らホモゲナイズし低温 $\left(0^{\circ} \mathrm{G}\right)$ で遠沈 $(6,000$ r.p.m., 20分)後上澄及び沈渣に分け，上澄はそれ

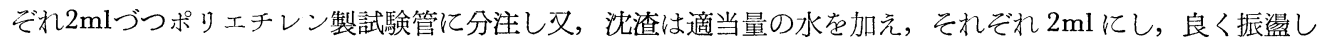
内容物を均等にした後, それ等の放射能を測定して, $\mathrm{Zn}^{65}$ の各組織に於ける分布を調へた。 $\mathrm{Zn}^{65}$ の量は, 各組織の単位重量 $(\mathrm{lg})$ 単位時間当りのカウント数 (c.p.m./gr) で表わし, 各組織の水溶性 $\mathrm{Zn}^{65}$ と不溶性 $\mathrm{Zn}^{65 *}$ は各々の組織の全 c.p.m./gr に対するそれぞれの百分率で表わした。 各群の平均值は Fisher $(1941)^{5)}$ の方法で統計処理した.

\section{実 験 成 績}

\section{（1）各組織の水溶性 $\mathrm{Zn}^{65}$ と不溶性 $\mathrm{Zn}^{65}$ の分布}

図のうち棒グラフで示したものが各組織の水溶性および不溶性の $\mathrm{Zn}^{65}$ の分布を表わす。乙机等の図から わかるように，正常ラッテにおいてもその值にかなりの変動がみられるが副腎剔出によりこれらの值が特に 水溶性の方に移つたり，不溶性の方へうつるという様なはつきりした傾向は見出せなかつた．また副剔後 DOCA 及び Cortisone 投与の場合も，正常ラッテ，副剔ラッテでみられた組織内の水溶性 $\mathrm{Zn}^{65}$ と不溶性 $\mathrm{Zn}^{65}$ の比率に影響を与えることは少なくほぼ同じ割合で組織の中に含まれることが知られる。しかしすべて の組織を詳細に検討すると, 水溶性 $\mathrm{Zn}^{65}$ の多い組織は, 脳下垂体, 甲状腺, 膵藏, 肝臓, 腎臓, 脾藏でみ られた。特に膵藏では組織内の全 $\mathrm{Zn}^{65}$ 量の70 $80 \%$ が水溶性 $\mathrm{Zn}^{65}$ として存在している. それに対して筋 肉, 精囊及び前立腺には，その大部分が不溶性 $\mathrm{Zn}^{65}$ として存在し，筋肉，精霊は約 $80 \%$, 前立腺では $70 \%$ が不溶性 $\mathrm{Zn}^{65}$ として存在している。そこの他の組織であおおむね各処置群による差異にはつきりした傾向は みられず，水溶性 $\mathrm{Zn}^{65}$, 不溶性 $\mathrm{Zn}^{65}$ 共にほぼ同程度, あるいはいくぶん水溶性のあのにやや多くみられた。

(2) 注射後における各組織の Specific activity (c.p.m/gr) の時間的経過

\section{i ）脳下垂体及びそれと類似の傾向を示す組織}

脳下垂体の Specific activity をしらべると，正常ラッテにおいて activity が最大になるのは実験開始 2 日後にピーク (124,000 c.p.m./gr)がみられ，その後急速に減少し 5 日及び10日後ではずつと少くなつて来る. これに対し副剔すると Specific activity のピークはやはり 2 日後にあるけれどあその activity はずつと少 ない (82,000 c.p.m./gr). しかし正常のものに比べると減少の速度はおそく，10日後においては未だ正常のも のの約 2 倍に相当する activity をもつている (66,000 c.p.m./gr). これに対して DOCA, Cortisone を注射 した副剔ラッテは, activity がピークに達してからの減少の速度は, 正常のものにみられるようなカーブを 画いて減少し，10日後では大体同じ activity をむつようになつた．脳下垂体の場合は DOGA よりも Cortisone 投与群において, 正常ラッテでみられたと同じ傾问のカーブを示した. 同じような傾向は甲状腺及び 顎下腺であみられた。後 2 者の場合には正常ラッテの甲状腺, 買下腺における activity のピークの值は夫々

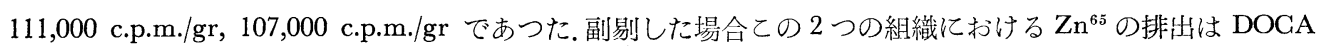
投与群よりあ Cortisone 投与群において正常ラッテのカーブに近い值が得られた，且つ揕取された $\mathrm{Zn}^{65}$ の 排出はいづれの場合であ副剔するととによりかなりおくれるととは特徽的である.

\section{ii）胸腺及びそれと類似の傾向を示す組織}

胸腺では正常ラッテは脳下垂体之同様 $\mathrm{Zn}^{65}$ 注射 2 日後に Specific activity が最大 (120,000 c.p.m./gr)

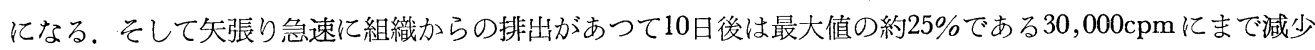
してしまう。关れに対して副剔すると Specific activity が最大に達するまでの時間がおくれ， $\mathrm{Zn}^{65}$ 注射 5 日後に最大值になる (124,000 c.p.m)。 この後の減少の仕方は, ほぼ正常ラッテの排出と平行した速度で排

* 水溶性, 不溶性の区別は化学的に煆密ではないが，この条件下に溶存するものを水溶性とし沈澱するも のを不溶性とした。 
出されてりく．また副剔ラッテに DOGA 又は Cortisone を投与した場合は完全ではないが，正常ラッテの 代謝の㑯向に近づき activity の最大值は異なるが，大体 2 日前後にそのピークがあらわれ，それから急速に 減少していく. 特に DOCA 投与群では 5 日から10日後にかけての減少の割合はほとんど正常ラッテのそれ に一致する，同じ傾向を示す組織は，耳下腺，腎藏，脾藏，精囊，前立腺にみられる，正常ラッテでのこれ 等の組織における Specific activity は夫々 87,$000 ; 154,000 ; 155,000 ; 42,000 ; 164,000$ c.p.m./gr であつた. この際副剔群における c.p.m./gr の最大が正常ラッテのそれよりずつと多くなる組織として，精霊 $(70,000$ c.p.m./gr) 前立腺 (194,000 c.p.m./gr) であつた.

iii）幸丸及びそれに類似の傾向を示す組織

睪丸における $\mathrm{Zn}^{65}$ の掑取は他の組織よりもおくれ，最大の Specific activity を示すのは， $\mathrm{Zn}^{65}$ 注射後 5

1. Hypophysis

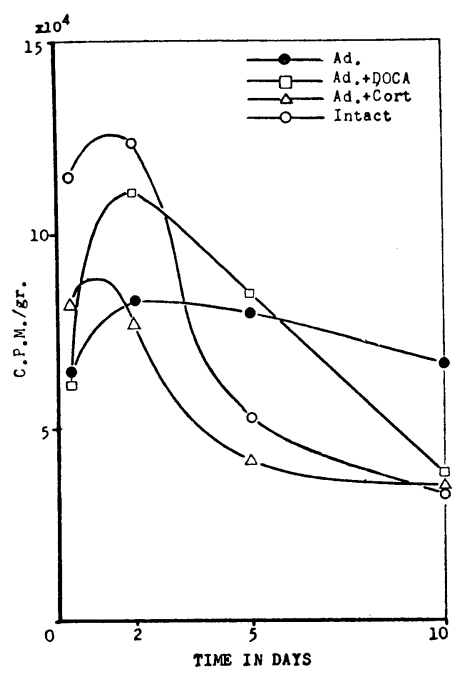

2. Thyroid gland

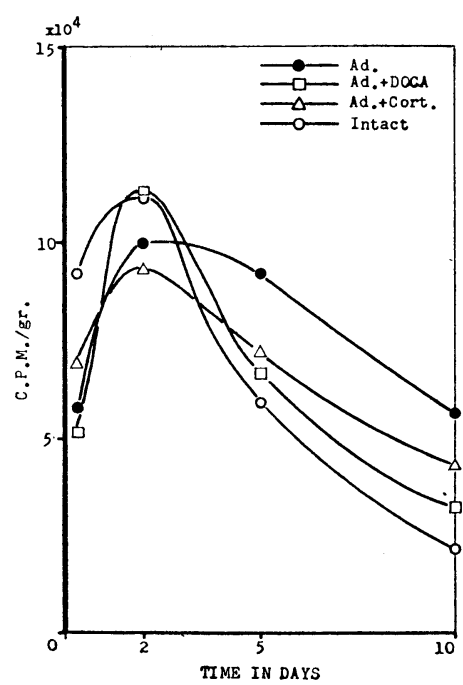

図の説明

各種藏器に打ける $\mathrm{Zn}^{65}$ の代謝．棒グラフは水溶性 $\mathrm{Zn}^{65}$ と不溶性 $\mathrm{Zn}^{65}$ の分 布. 曲線グラフは各藏器に 扣けるSpecific activity の 変化.

1. 脳下垂体

2. 甲状腺

3. 顎下腺

4. 胸腺

5. 耳下腺

6。腎臓

7. 脾藏

8. 貯精襄

9. 前立腺

10. 䈉丸

11. 筋肉

12a. 血液

12b. 副腎

13. 膵藏

14. 肝臟

ad，副腎剔出ラッテ; $\mathrm{ad}+\mathrm{DOCA}$ ，副腎剔出亏 ッテに DOGA 投与; $\mathrm{ad}+\mathrm{cort}$, 副腎剔出ラッテ 飞 cortisone acetate 投与； Intact, 正常ラッテ 

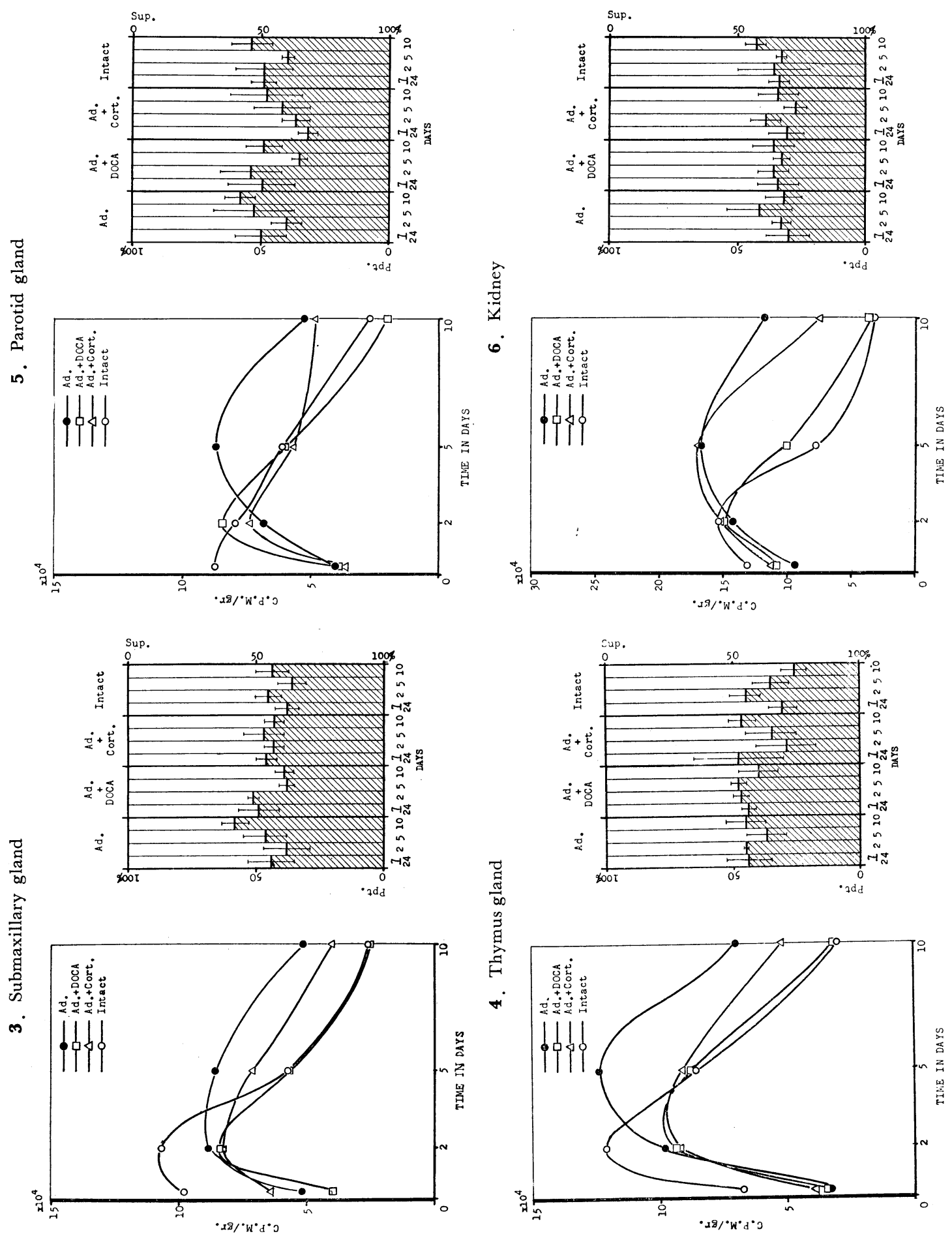

第36巻 第 8 号 

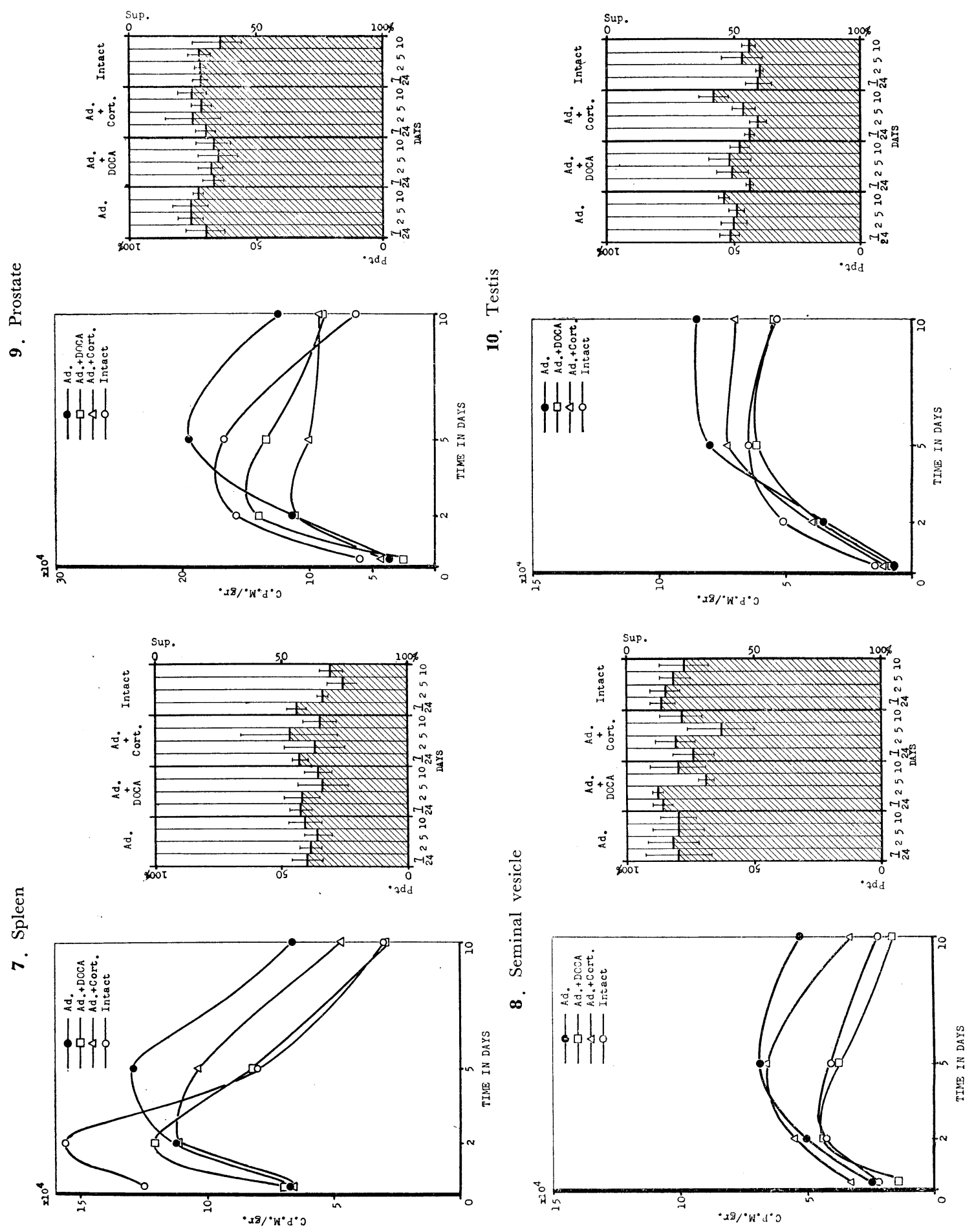

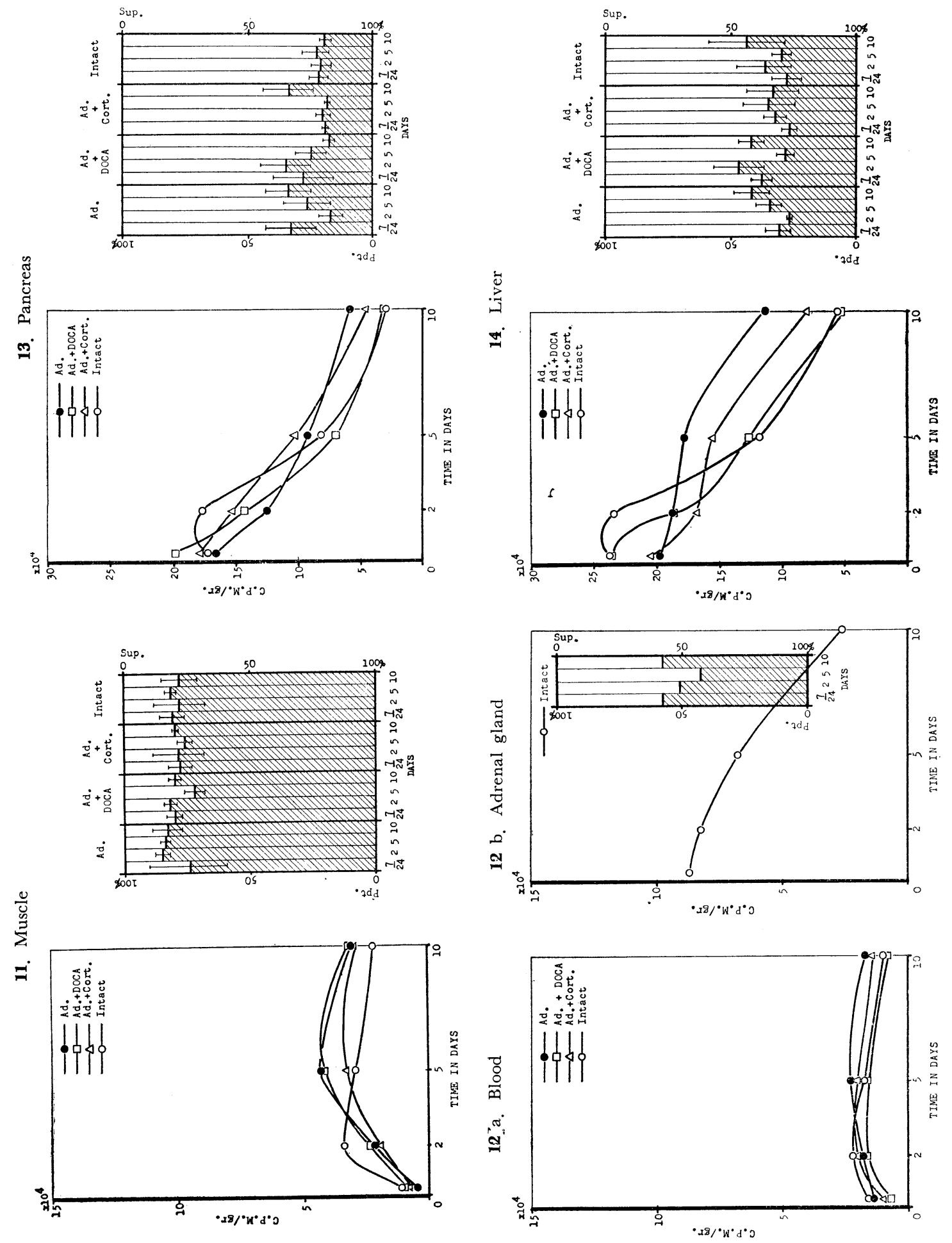

第36巻 第 8 号 
日あるいはむつと後にピークが見られた，今回の実験では，正常睪丸は $\mathrm{Zn}^{65}$ 注射 5 日後に最大值 $(65,000$ c.p.m./gr) を示し，その後の排出も極めて緩慢であり10日経過しても 55,000c.p.m./grの 值を維持している. この傾向は, 副腎を剔出することによつて更にはつきりあらわれ,注射10日後であ未だその Specific activity は増加の傾向にある (10日後の activity 85,000 c.p.m./gr.). しかし睪丸もこれまでのべた諸藏器と同様に DOGA 又は, Cortisone 投与により正常值に近くなる傾向を示し，特に DOCA 投与群ではほとんど正常 と同じカーブを画いて減少していく，同様に摂取された $\mathrm{Zn}^{65}$ の排出が緩慢な組織は，筋肉及び血液に見出 される，正常ラッテにおけるこれら 2 つの組織は他の組織より Specific activity は少なく筋肉は 34,000 c.p.m./gr，血液はわづか 22,000 c.p.m./gr を示したにすぎない.

ここで他の組織の場合といくぶん異なるのは筋肉であつて，副剔によつてひきおこされた $\mathrm{Zn}^{65}$ の摂取， 排出のおくれは DOCA, Cortisone 投与によつてもほとんど正常值にもどる傾向を示さない.

\section{iv）膵臓及びそれに類似の傾向を示す組織}

膵臓で最もいちぢるしいことは, Specific activity の最大ピークが大きいと共に, その摂取の速さも極め て大きく, 大体 7 時間から 2 日後に最大值に達し $(180,000 \mathrm{c.p} \cdot \mathrm{m} . / \mathrm{gr}$,). その後急速に減少していく. ての傾 向は副剔により更にはつきりし，7時間で最大值を示し (166,000 c.p.m./gr) 以後ずつと減少する. しかし， 副剔による排出のおくれは膵臓にもみとめられ, 10日後における正常ラッテと比べるとほぼ倍のSpecific activity をむつている (正常ラッテ30,000 c.p.m./gr, 副剔ラッテ60,000 c.p.m./gr). DOGA, Cortisone の注射 を行うと膵臓む大体正常ラッテにおいてみられるカーブに接近する傾向が示され，特に DOGA 投与群の方 がその傾向が溞い，ほとんど類似の傾向を示すむのは肝蔵であつて，図でみられるごとく膵臓と全く同じよ うなカーブを画いて摄取排出される.

附加的に正常ラッテにおける副婜における $\mathrm{Zn}^{65}$ の椇取率を測定したところ，大体膵蔵あるいは肝臟と似 た傾向がみられた。

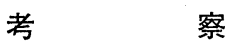

$\mathrm{Na} ＼textrm{K}$ 等の代謝が副婜皮質ホルモンによりコントロールされているととは衆知の事奏であるが，いわゆる 重金属が同じように考えることが出来るかどうかは不明である。しかし今回筆者の行つた実験は，副剔の効 果が DOCA, Cortisone を与えることによつて正常ラットの各種藏器における $\mathrm{Zn}^{65}$ のとりこみ, 排出のレ ベルに復元し，または復元の傾向を示したことは，重金属の代謝が副腎皮質ホルモンと全く無関係でないこ とを示唆するものといえよう。しかしながら銅, 鉄, ニッケル, コバルト, 等 Zn 以外の体内微量金属にも このことが言えるかどうか今後更に問題とされなければならない.

Montgomery, Sheline および Chaikoff $\left(1943^{18)}\right)$, Sheline et al. $\left(1943^{19)} ， 1943^{20)}\right)$ らは犬およびマウスを用 いて $\mathrm{Zn}^{65}$ の代謝実験を行い，投与. $\mathrm{Zn}^{65}$ は肝臟，膵藏，腎藏及び絾下垂体に容易に摂取され且つその排出む 速いと述べている．更に $\mathrm{Zn}^{65}$ の代謝速度のおそい臓器として赤血球，脸骨格筋及び皮膚をあげ，その中間 的なむのとして脾藏, 腸管, 副腎, 肺, リンパ球, 脳, 心㵴及び胸腺をあげている. 又 Gilbert および Taylor $\left(1956^{6}\right)$ ) は同じように $\mathrm{Zn}^{65}$ をラッテに注射するととにより，各種藏器中に取り込まれるが，特に筋因，赤 血球，睪丸及び小腸へのとり込みは極めておそいとのべている．乙れらのデータと今回の実験結果を比較す ると，すべての点で一致しているわけではないが膵蔵，肝臓等の藏器でみられるようにその代謝速度が速い こと，また筋肉，血液，鋅丸等にみられる極めて緩慢な摂取，排出がみられる等かなりの点で前に引用した 研究者のデータと合つている。乙れ等の結果は各組織中には多少なりとも，血液があるから，その中に含ま れている Zn と結合した醭素, 炭酸脱水素酳素のことあ考慮しなければならないだろうが，血液での緩慢且 つ比較的小さい Specific activity を考えると結果で示された組織の Specific activity は, 血液にとり込ま れた $\mathrm{Zn}^{65}$ の為ではなく臓器実質に取り込まれるあのの変動と見るのが正しいであろう. 又 Metalloenzyme として Zn を含み且つ組織の正常な活動と必要欠くべからざる酵素の存在が確められている (Adelstein 1958

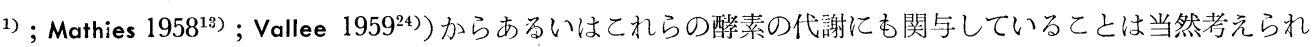


る. 又 $\mathrm{Zn}^{65}$ の組織内への掑取，排出がホルモンの影響によつていちじるしい変化を受けることは多くの研

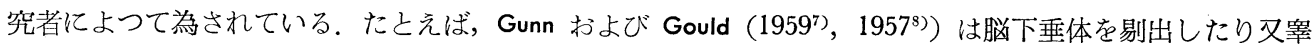
丸を剔出したりするととと，Androgen 又は Estrogen を投与するととなどを並用して前立腺春側葉にとり こまれる $\mathrm{Zn}^{65}$ の量をしさいにしらべた。そそれによると，前立腺への $\mathrm{Zn}^{65}$ のとりとみは脳下垂体を摘出す ることにより低下するがての際適当量の胎盤性 Gonadotoropin 又は Testosterone を投与するとこの低下が みられない，乙の際，睪丸を除去してああまりいちじるしい変化を来たさない．また Estradiol あ適当量投 与した時には Testesterone と同じ働きがあるが，より大量の Estradiol はむしろ逆効果を表わし， $\mathrm{Zn}^{65}$ の 前立腺への取込みか抑制される。 また，Testosterone と Estradiol もとの投与量によつて場合によつては $\mathrm{Zn}^{65}$ の取り込みを促進し，場合によつては抑制する。同様な実験は Kar, Pover および Boscott $\left(1956^{11)}\right)$ に よつても報ぜられており，いづれにしても前立腺への $\mathrm{Zn}^{65}$ の取り込みが，性ホルモンと深い関係にあるて とを示している。しかしながらてれ等の現象がはたしてどのような作用機構に従つてあらわれるかについて はほとんどわかつていない。

今回の実験結果では, 藏器の如何を問わず副腎剔出が投与 $\mathrm{Zn}^{65}$ の組織内への取り込みあるいは排出をお くらせているが，一方ての現象は DOCA あるいは Cortisone 投与によりかなり改善されている. Vallee

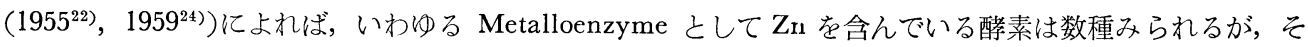
の中には, Carbonic anhydrase, Carboxypeptidase, Glutamic dehydrogenase, Alkaline phophatase 等の 組織の活動に重要な酥素が含まれており Zn の正常代謝が阻止された場合は少くとも動物体には好ましい条 件であるとは云えないであろう. いづれにしても多くの醭素と結合し, または酥素活性の Co-factor として 最近重要な意味を附与されてきた Zn が副剔により代謝が阻害されることは，Zn の生理的意義に重要な意 味が与えられるあのと解せられる。しかもこれが DOCA, Cortisone 投与により復元を示すととは重金属代 謝と言う面から考えても更に追求されねばならない問題である。

最後に投与 $\mathrm{Zn}^{65}$ の各藏器中での水溶部にあるか，あるいは不溶部に多いかと言うととについて簡単に附 け加えたい. 前にのべたように投与 $\mathrm{Zn}^{65}$ が水溶性部に特に多く現われるのは, 脳下垂体, 甲状腺, 膵臓で あり，睪丸や精靈，前立腺等はその逆に不溶部分に多い，乙れらが如何なる意味を有しているかどうかはま だ何の手がかりも得られないが，乙れらの分布から得られることは，蛋白性ホルモンに関与しているものは すべてではないが水溶性部に多く, 又 Steroid 系のホルモンに関与している藏器には $\mathrm{Zn}^{65}$ が不溶性部に見出 だされたととがわかる。この点しばしばのべられている如く，(Fischer および Scott 19354); Maxwell 1934 ${ }^{16)}$; Vallee 1956 ${ }^{25)}$; Banghart および Watanabe 1956 ${ }^{2)}$ ) 蛋白系ホルモンがZn の存在によりそのホルモン作

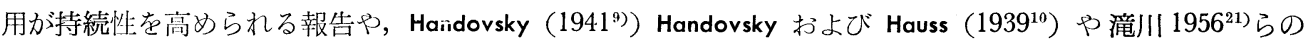
述べているように, 蛋白系ホルモンを産出する内分泌組織では水溶性部に Zn が多く, また Steroid 系木 ルモンに関係している組織は不溶性部に多いという報告功しても, 組織中の, 水溶性および不溶性 $\mathrm{Zn}^{65}$ の 分布は内分泌の活動に興味深い問題を投げかけているように思われる。 この点について更に進んだ研究と詳 しい検討が為さるべきである.

\section{総括}

ラッテの各種内分泌器管及びその他の藏器, 脳下垂体, 甲状腺, 胸腺, 耳下腺, 類下腺, 膵藏, 睪丸, 精 囊, 前立腺, 肝臟, 脾藏, 筋肉及び血液における亜鉛の代謝を, $\mathrm{Zn}^{65}$ を筋肉内に注射した正常, 副腎剔出及 び副剔後 DOCA, Cortisone を投与したラッテについてしらべ次の結果を得た.

1. 各絊織を水溶性部之不溶性部之に分けて, 摃取された $\mathrm{Zn}^{65}$ を測定した結果, 脳下垂体, 甲状腺, 膵

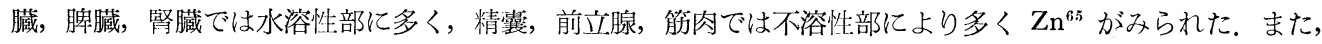
耳下腺，顎下腺，睪丸では水溶性部及び不溶性部共に同じ程度に分布していた.

2.一般にいづれの組織であ, 副婜剔出によつて投与 $\mathrm{Zn}^{6.5}$ の摄取がおくれるようになり, 又排出も正常 ラッテのそれに比べおそくなる。 
3. 副腎剔出により生じた $\mathrm{Zn}^{65}$ の揕取，排出のおくれは，DOCA，Cortisone 投与により正常ラッテの それに復元，又は復元の傾向を示す．しかしながら多くの組織で Cortisone よりDOCA の方が，副剔によ る $\mathrm{Zn}^{65}$ の摂取, 排出の遅れを阻止する力が溞い.

4.以上の結果から $\mathrm{Zn}^{65}$ の摂取，排出には副腎皮質ホルモンが関係していることが考えられ，またその 他の内分泌腺であ蛋白性ホルモンに関係ある組織と，ステロイド系ホルモンに関係した組織とは，それぞれ 別の意味で西鉛と密接な関係のあることが考えられる.

終句に臨み，御指導と御校閲をいただいた滝川泱男教授に深甚なる謝意を表わします。

\section{参 考 文 献}

1) Adelstein, S.J. \& Vallee, B.L. : J. Biol. Chem., 223, 3, 1958.

2) Banghart, H.E. \& Watanabe, R.K.

: Amer. Prac. Digest Treatm., 7, 1957, 1956.

3) Drinker, K.R. \& Collier, E.S. : J. Ind. Hyg., 8, 257, 1926.

4) Fischer, A.M. \& Scott, D.A. : Biochem. J., 29, 1055, 1935.

5) Fischer, R.A. :

Statistical method for research workers, 8th Ed. Oliver and Boyd.

6) Gibert, I.G.F. \& Taylor,

D.M. : Biochim. biophim. biolphys. Acta, 21, 545, 1956.

7) Gunn, S.A. \& Gould, T.C. : Endocrinol.,
58, 443, 1956.
8) Gunn, S.A. \& Gould, T.C. : J. Endocrinol., 16, 18, 1957.
9) Handovsky,

H. : Arch. Int. Pharmacodyn., 66, 460, 1941.

10) Handovsky, H. \& Hauss, L. : Bull. Soc. Chim.

Biol., 21, 112, $1939 . \quad$ 11) Kar, A.B., Pover, W.F. \& Boscott, R.J. : Acta Endocrinol., 22, 390, 1956.

12) Koch, H.J. Jr. \& Smith, E.R. : J. Clin. Endocrinol. Met., 16, 123, $1956 . \quad$ 13) Mathies, J.C. : J.

Biol. Chem., 233, 1121, $1958 . \quad$ 14) Mawson, C.A. \& Fischer, M.I. : Nature, 167, 859, 1951.

Mawson, C.A. \& Fischer, M.I. : Can. J. Med. Sci., 30, 336, $1952 . \quad$ 16) Maxwell, L.C. : Amer. J. Physiol. 110, 458, $1934 . \quad$ 17) Millar, M.J., Elsoate, P.V. \& Mawson, C.A.: Cnad. J. Biochem· Physiol., 35, 856, $1957 . \quad$ 18) Montgomety, M.L., Sheline, G.H. \& Chaikoff, 1.L. : J. Exp. Med., 78, 151, 1943.1 19) Sheline, G.E., Chaikoff, I.L., Jones, H.B. \&Montgomery, M.L. : J. Biol. Chem., 147, 409, 1943.2 20) Sheline, G.E., Chaikoff, I.L., Jones, H.B. \& Montgomery, M.L. : J. Biol. Chem., 149, 139, 1943.21 滰川深男 : ポーラログラフ討論会, 1956.22$)$ Vallee, B.L. : Zinc and metalloenzymes in "Advance in Protein Chemistry" Ed. by Anson, M.L., Bailey, V. \& Edsall, J.T. New York : Acad. Press, $1955 . \quad 23)$ Vallee, B.L. : J. Amer. Med. Assoc., 162, 1053, 1956.

Vallee, B.L. : Physiol. Rev. 39, 443-490, 1959.

25) Wolff, H. : Klin. Wochschr., 34, 409, 1956.

26）小野恵子：日本内分泌学会雑誌，36，1421，1960. 